\title{
Does the Entrepreneurial Human Capital is Important for Organizational Performance?
}

\section{Saqib Amin*}

Department of Economics, University of Lahore, Lahore, Pakistan

\begin{abstract}
The study investigates the relationship between entrepreneurial human capital and performance of organizations in Pakistan. It adopts quantitative methodological framework which collected data from annual reports of selected organizations registered in Lahore Stock Exchange (LSE) of Pakistan. This study used both Regression analysis and correlation techniques to find the relationship and degree of relationship between entrepreneurial human capital and organizational performance. The findings show that entrepreneurial human capital (Education, Experience and skills) are positively associated with the performance of organizations. Organizations are encouraged to adopt good entrepreneurial human capital practices to improve their performance and also to protect the interest of the shareholders.
\end{abstract}

Keywords: Entrepreneurial human capital; Lahore stock exchange; Organizational performance

\section{Introduction}

There are number of factors which affect the organizational performance, in which one of the most commonly known is human capital. Investment in human capital (Education, Experience, and Knowledge) creates multi-dimensional benefits for the economy. However human capital is vitally important for an organization's success [1]. The concept of Entrepreneurial human capital merges management and finance subjects into economics field. Entrepreneurial human capital is related to the components of entrepreneur's education, experience, skills, and training which are found one of the dominant factors for organization's performance [2-4].

Pakistan has ranked 113 out of 124 and last in Asia and Pacific region, it means human capital in Pakistan is far behind from Bangladesh, Bhutan, India and Nepal. In the case of ASEAN countries where we found only one dominant factor, which increase the productivity of individuals and organizations is human capital and those entrepreneurs which have better knowledge, education and skills have better impact on organizational performance [5]. Entrepreneurial human capital not only increases the profitability of firm but also increases the strength, sustainability and longevity of the organization's [6]. Entrepreneur's human capital directly impacts on organizational performance of those entrepreneurs who have greater capacity to translate education and training into higher earnings and will have a higher ability to capture the market as compared to other entrepreneurs. Entrepreneurs have not inherited skills but it is long way process which can be learned through educational institutions and training programs, that enables the individual to become a successful entrepreneur.

Almost all researchers are agreed regarding the entrepreneurial activity is remarkably and robustly persistent. Endogenous accumulation of entrepreneurial human capital like knowledge, skills, decision making and risk judgment enhance the productive capacity, competencies to engage in more enterprising, innovative skills $[7,8]$. Entrepreneurial education provides potential knowledge and skills regarding the market research, business planning and negotiation techniques. There is no secret that entrepreneurs think differently. They have spirit of competitiveness, challenging attitude and much more creative presentation ways. Successful entrepreneurs actually use a different reasoning approach while making decisions about their business. It is important to note that entrepreneurs are differentiated from managerial or strategic point of view. They believe in making future and setting goals to accept change and groom over time. Most successful entrepreneurs begin with effectual thinking when developing an idea and move towards causal reasoning, and latter part of a project's development.

The concept of entrepreneurial human capital, understood as the source of valuable professional knowledge and skills which is the process of education and experience. Effective leadership acts as a spark for organizational knowledge which in turn allows top management to align values throughout the organization. Entrepreneurial human capital is positively influenced by the commitment of its organizational performance and their ability to generate new knowledge. In these days business environment have become global and highly competitive, every organization has no option, but to grow for survival. The importance of entrepreneurial human capital is increasing day by day, as seen the markets are becoming more competitive. Recently markets need to strategize in order to deliver excellence in their services and products that can attain a competitive edge among consumers [9].

Professional education, knowledge and skills reduce the risk of failure and increase the confidence of entrepreneurs. Entrepreneurial human capital is not only one factor phenomena but the entire variables are recorded to apply simultaneously for better performance [4]. To know about, why the same level of entrepreneur's position creates different impact on organizational performance and those entrepreneur's which have better knowledge, skills and ideas they go faster than other in this race of competitive world, because survival in this competitive world is not an easy job. An entrepreneurial human capital change the mind set of CEO's and thus changes the vision and mission statement of organization. Entrepreneurial human capital enhances personal and organization values in better way. The entrepreneurial human capital provides the ability of financial potential,

*Corresponding author: Amin A, Department of Economics, University of Lahore Lahore, Pakistan, Tel: 9242 111865865; E-mail: saqib.amin000@gmail.com

Received November 19, 2017; Accepted April 30, 2018; Published May 07, 2018

Citation: Amin S (2018) Does the Entrepreneurial Human Capital is Important for Organizational Performance? Bus Eco J 9: 350. doi: 10.4172/2151-6219.1000350

Copyright: (c) 2018 Amin S. This is an open-access article distributed under the terms of the Creative Commons Attribution License, which permits unrestricted use, distribution, and reproduction in any medium, provided the original author and source are credited. 
financial freedom, better idea to meet and manage financial constraint. Entrepreneurial human capital provides the ability to face risk taking and risk aversion situation, reduce pressure, avail opportunity, respond quickly, and ability to solve problems. The typical research design in this field examines the progress of entrepreneur's human capital over time. Entrepreneurial human capital is actually based on education, experience and some other variables.

The theory of human capital has been in debate since its notion in economic development. Different economists divert this view toward the importance of human capital in entrepreneurship. Small and medium size organizations play a key role in economic growth of Pakistan, but the performance of organization's mainly depend on entrepreneurial human capital. McGuirk et al. [3] extends the concept of innovative human capital and emphasizes its effect on small firm innovation and hence economic growth through productivity. The study concluded that the concept of innovative human capital as a competitive advantage, moreover explored the determinants of small firm innovation. This study discussed innovative human capital as a significant concept to consider the public support programs for small firms. Sehhat and Fooman [4] illustrated the effects of entrepreneurial knowledge dimensions on small firm's performance by developing a model in Iran. The result shows the knowledge dimensions on firm performance have a positive and significant impact on firm's performance; moreover knowledge dimension has rigorous effects on growth than profitability. They showed the effect of education on firm's growth was $0.29 \%$ and $0.21 \%$ on firm's profitability. The effect of skills on firm's growth was $0.66 \%$ and $0.51 \%$ for firm's profitability. The effect of work experience on firm's growth was $0.38 \%$ and $0.36 \%$ on firm's profitability.

Chimucheka [2] shows the impact of entrepreneur's education on the establishment and survival of small, micro and medium enterprises, in the South Africa by using both primary and secondary data in the study. This study concludes that entrepreneurial education can play a significant role in the establishment and survival of SMMEs in South Africa. The findings of this research showed that entrepreneurship education is very important for the establishment and survival of enterprises. Njoroge and Gathungu [10] showed entrepreneurship's education and training has been found a major determinant of the growth and survival of enterprises in Kenya. This study concluded that even though the entrepreneur reporting an increase in sales and profits might seem to be registering growth, but due to lack of entrepreneurial education and training the small \& medium size enterprises would not grow beyond the first stage, eventually fails within its first five years of existence.

Baptista et al. [11] examines, whether entrepreneur's background influence new firm survival in the early years after commencing business. Those entrepreneurs after leaving previous employment when joins a new firm, then play a key role in enhancing early survival chances. This study concluded that pre-entry capabilities play an important role in the early success of opportunity-based entrepreneurs, but have little influence on the early success of necessity-based ones. They also concluded that low level of entrepreneurial human capital means limited chance to early survival of small size firm [12].

Rashid et al. [13] showed that intellectual capital is most important and study observed the pressure of intellectual capital on progression of telecom sector of Pakistan. Their study concluded that there is association between intellectual capital and performance of an organization, and there is positive relation between intellectual capital and performance of telecom sector of Pakistan.
Many studies have been conducted to find the relationship between entrepreneurial human capital and organizational performance, but most of them are conducted for the countries other than Pakistan. Hardly any study exists in the context of entrepreneurial human capital in case of Pakistan. The above mentioned studies mostly focused on single variable to explore entrepreneurial human capital's impact on organizational performance. Therefore, this is first study which will cover all those variables of entrepreneurial human capital such as entrepreneur's education, experience, skills to explore its impact on organizational performance. This is first study which checks the impact of entrepreneurial human capital on organizational performance in Pakistan. This study is the contribution in the literature of entrepreneurial human capital and provides guidance for further study in this field to increase the productivity of firm in competitive markets. This is the necessity of the time to improve the entrepreneurial human capital to improve the employment, profitability and growth of the organizations.

\section{Indentations and Equations}

Schultz [14] focusing on the debate of the role of human capital promotes new debate regarding its significance in economics, and individually on firm performance. In order to accomplish this empirical work, study focuses on the idea of human capital as floated by Becker [15]. Human capital theory shares the assumption of rational behavior with other microeconomic approaches. However, there are large set of potential applications of human capital theory, very few authors have tried to use the theory in analyses of entrepreneurial human capital and the profitability of small firms. This theory is further extended by Bates [16], which focuses on the effects of human capital endowments on minority business viability, by showing the positive relationship between entrepreneurial human capital and firm profitability. In the article of entrepreneurial human capital in relationship with organizational performance Bates [6] investigated impact of aggregated human capital on certain industries performance. So, the debate converted to the importance of the variables of entrepreneurial human capital such as education, experience, skills and their role in organizational performance (Figure 1).

To investigate the impact of entrepreneurial human capital on organization performance in Pakistan, a cross sectional study based on quantitative and qualitative data has been designed. We collected data from 250 organizations (out of 550) small, medium and large scale organizations of Pakistan from Lahore Stock Exchange by using Raosoft formula of sample size. To ensure the reliability of study, we have taken average of last five year data 2010-2014 for firm performance (Tobin' Q, ROA and ROE). The sample has been taken from different organizations such as garments industry, chemical, shoe, foods, and banks etc. Information regarding entrepreneurial human capital collected from annual performance of the reports of organizations. Further to check the relation between them, study used descriptive statistics, Spearman's Correlation, and ANOVA mythology.

The theories suggested that entrepreneurial human capital regarding entrepreneur's education; experience and skills are main determinants of organizational performance. This study, follows the methodology of Sehhat and Fooman [4] and develops model regarding entrepreneur's education, experience and skills and observes its impact on organizational performance. We have used skills as an interaction term of entrepreneur's education and experience. For organizational performance a lot of studies used Tobin's Q, for market efficiency/ performance, return on total assets (ROA) and return of equity (ROE) 
Citation: Amin S (2018) Does the Entrepreneurial Human Capital is Important for Organizational Performance? Bus Eco J 9: 350. doi: 10.4172/21516219.1000350

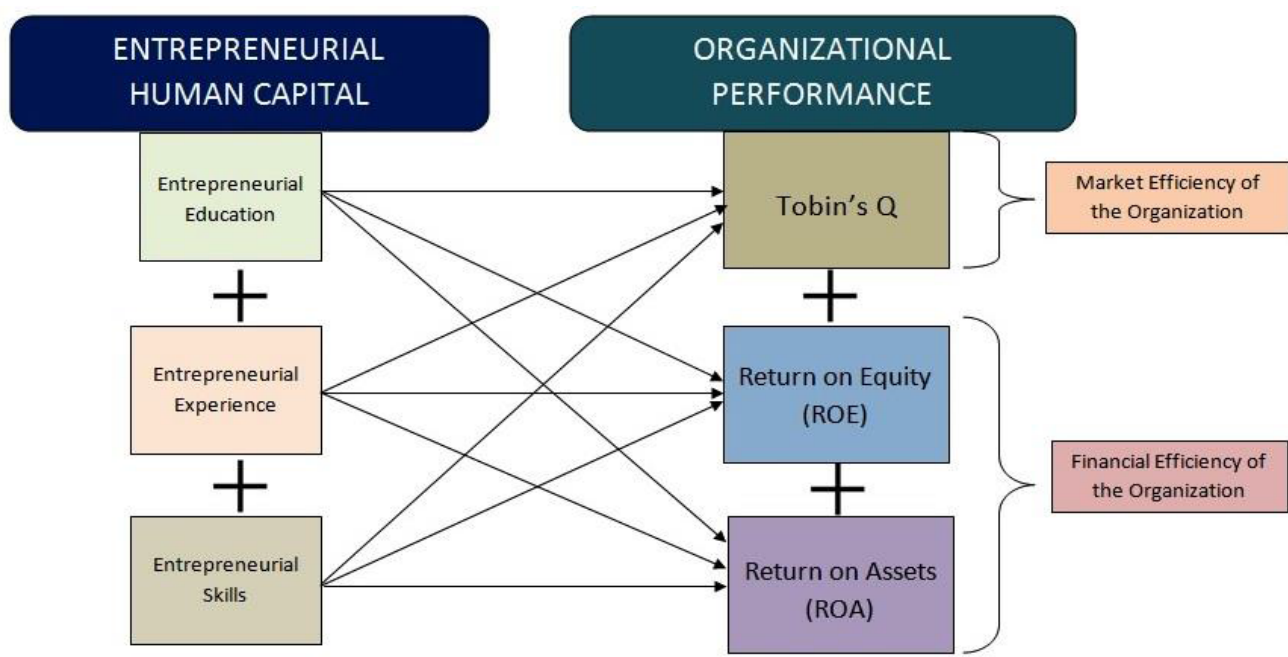

Source: Compiled by the author with amendment of Sehhat and Fooman (2014).

Figure 1: Theoretical model for Entrepreneurial Human Capital.

\begin{tabular}{|c|c|c|}
\hline Symbols & Variables & Measures \\
\hline \multicolumn{3}{|c|}{ Entrepreneurial Human Capital } \\
\hline EDU & Entrepreneurial Education & Ranking of Education Lower or 0 to Higher or 5 \\
\hline EXP & Entrepreneurial Experience & Ranking of Experience Lower or 0 to Higher or 5 \\
\hline SKI & Entrepreneurial Skills & Used as interaction term combination of education and experience \\
\hline \multicolumn{3}{|c|}{ Firm Performance } \\
\hline TQ & Tobin's Q & Market capitalization + total assets - shareholders' funds/total assets \\
\hline ROE & Return on equity & Profit after tax/shareholders' funds \\
\hline ROA & Return on total assets & Profit after tax/book value of total assets \\
\hline \multicolumn{3}{|c|}{ Control Variables } \\
\hline GEN & Gender & Male or Female \\
\hline LEAD & Leadership & CEO or Chairman (Separate or Combined) \\
\hline PRO & Qualification Standard & Dummy variables 0 for academic qualification and 1 for professional qualification. \\
\hline LOC & Qualification Scope & Dummy variables 0 for local qualification and 1 foreign qualification. \\
\hline
\end{tabular}

Table 1: Variables which has important role in determining the performance.

measurements. This model also includes some those control variables which has important role in determining the performance (Table 1).

$$
\begin{aligned}
& \mathrm{TQ}=\beta_{0}+\beta_{1} \text { edu }+\beta_{2} \exp +\beta_{3} \text { ski }+\beta_{4} \text { gen }+\beta_{5} \text { lead }+\beta_{6} \text { pro }+\beta_{7} \text { loc }+\varepsilon_{0} \\
& \mathrm{ROE}=\beta_{0}+\beta_{1} \text { edu }+\beta_{2} \exp +\beta_{3} \text { ski }+\beta_{4} \text { gen }+\beta_{5} \text { lead }+\beta_{6} \text { pro }+\beta_{7} \text { loc }+\varepsilon_{0}(2) \\
& \mathrm{ROA}=\beta_{0}+\beta_{1} \text { edu }+\beta_{2} \exp +\beta_{3} \text { ski }+\beta_{4} \text { gen }+\beta_{5} \text { lead }+\beta_{6} \text { pro }+\beta_{7} \text { loc }+\varepsilon_{0}(3)
\end{aligned}
$$

A lot of studies used entrepreneur's education for organizational performance. This is a qualitative variable which depicts ranking of education categories, 0 of illiterate or under-matric, 1 for matric, 2 for intermediate, 3 for graduation, 4 for Master, and 5 for M. Phil or Ph.D.

Entrepreneur's Experience: Labour market experience is one of the important determinants of entrepreneurial human capital. We take ranking of experience categories as 0 for 0-5 years' experience, 1 for 6-10 years, 2 for 11-15 years, 3 for 16-20 years, 4 for 21-25 years, 5 for $25+$ years. Next variable is Entrepreneur's Skills means a combination of education and experience. Management skills also develop from experience. Managerial skills and international expertise can be acquired through a combination of education and experience. Therefore study uses interaction term for entrepreneurial skills in the form of combination of experience and education Skills $=($ Education * Experience).
Tobin's Q: Tobin's Q market-based measure will be used to indicate the market perception of the firm's performance. Tobin's Q compares the ratio of a company's market value and the value of a company's assets. This study employs the methodology used by Adams and Mehran [17]; Rashid et al. [13] to calculate Tobin's Q, which is as follows:

Tobin's Q=Market Capitalization+Total Assets - Shareholder Funds/Total Assets.

Return on Equity (ROE): Return on equity measures the rate of return on shareholders' equity. It shows how well the company uses the shareholders investments to generate earnings. This measures the efficiency of generating profits of shareholders equity. ROE is best measurement regarding firm performance.

Return on Equity (ROE)=Profit After Taxation/ Shareholder Funds.

Return on Assets (ROA): Return on assets shows the profitability of the company's assets in generating profits. It indicates the effectiveness of the company's assets in increasing shareholders economic interests.

Return on Assets $(\mathrm{ROA})=$ Profit After Taxation/Total Assets.

Large number of studies has taken gender as important variable in the field of entrepreneurship and venture success. Whereas, Zeffane 
Citation: Amin S (2018) Does the Entrepreneurial Human Capital is Important for Organizational Performance? Bus Eco J 9: 350. doi: 10.4172/21516219.1000350

[18] provided statistical evidence that both male and female have same entrepreneurial potentials. For measuring leadership study uses Dummy variable 0 for combined leadership and 1 for separate leadership and there is strong evidence in support of the separate leadership structure. Haniffa and Hudaib [19] reported that companies which had a combined leadership structure did not perform as efficient as separate leadership structure.

\section{Statistical Results and Analysis}

The below table show the summary of descriptive statistic including means, standard deviations and range of major variables that have been used in our study.

The sample of 250 organizations selected for this study, whereas the qualification of entrepreneur's divided into 5 categories represented as minimum 1 to maximum 5 (Tables 2-4). The means error value of entrepreneur's qualification is 0.063 . A skill used as combination of qualification and experience which shows minimum value 2 to 136 with mean error value of 1.834 , whereas dummy variables 0 and 1 used for local degree holder or foreign degree holder, academic degree or professional degree, single or combined CEO, male or female respectively. Whereas for organizational performance used ROA, ROE and Tobin's $Q$ which shows minimum 7.76, 9.12 and -.06 to maximum 87.87, 30.08 and 9.85 respectively (Appendices Tables 1-8).

The above mentioned results of analysis of variance (ANOVA) showed that Entrepreneur's education, experience and skills significantly affect the organization's financial and market performance. Whereas other control variable like corporate leadership, gender, professional degree also main contributor of organizational output/performance.

\section{Conclusion}

This study shows the robust result regarding the micro level

\begin{tabular}{|l|c|c|c|c|c|}
\hline ANOVA $^{\mathrm{a}}$ Model & Sum of Squares & Df & Mean Square & F & Sig. \\
\hline Regression & 6816.755 & 7 & 973.822 & 2.241 & $.032^{\mathrm{b}}$ \\
\hline Residual & 105160.2 & 242 & 434.546 & & \\
\hline Total & 111977 & 249 & & & \\
\hline
\end{tabular}

apependent Variable: ROA

bPredictors: (Constant), edu, exp, ski, loc, pro, lead, gen

Table 2: Regression analysis of variance (ANOVA) showed that Entrepreneur's education, experience and skills significantly affect the organization's financial and market performance on variable ROA.

\begin{tabular}{|l|c|c|c|c|c|}
\hline ANOVAa Model & Sum of Squares & Df & Mean Square & F & Sig. \\
\hline Regression & 490.173 & 7 & 70.025 & 2.215 & $.034^{\text {b }}$ \\
\hline Residual & 7652.272 & 242 & 31.621 & & \\
\hline Total & 8142.445 & 249 & & & \\
\hline $\begin{array}{l}\text { aDependent Variable: ROE } \\
\text { bPredictors: (Constant), edu, exp, ski, loc, pro, lead, gen }\end{array}$ & \\
\hline
\end{tabular}

Table 3: Regression analysis of variance (ANOVA) showed that Entrepreneur's education, experience and skills significantly affect the organization's financial and market performance on variable ROE.

\begin{tabular}{|l|c|c|c|c|c|}
\hline ANOVA $^{\text {a Model }}$ & Sum of Squares & Df & Mean Square & F & Sig. \\
\hline Regression & 162.456 & 7 & 23.208 & 3.992 & $.000^{\mathrm{b}}$ \\
\hline Residual & 1406.978 & 242 & 5.814 & & \\
\hline Total & 1569.434 & 249 & & & \\
\hline $\begin{array}{l}\text { aDependent Variable: Tobin's Q } \\
\text { bPredictors: (Constant), edu, exp, ski, loc, pro, lead, gen }\end{array}$ & \\
\hline
\end{tabular}

Table 4: Regression analysis of variance (ANOVA) showed that Entrepreneur's education, experience and skills significantly affect the organization's financial and market performance on variable Tobin's $Q$. prospective of entrepreneurial human capital on organizational performance in Pakistan. This study concluded that entrepreneur's human capital i.e., education, experience and skills have positive significant impact on organization performance. It adopts quantitative methodological framework and data has collected from annual reports of selected organizations registered at Lahore Stock Exchange. The study showed that entrepreneurial human capital (Education, Experience and skills) are positively associated with the performance of organizations. The results encourage adopting good entrepreneurial human capital practices to improve their performance and also to protect the interest of the shareholders. These results suggested a policy implication that government should take step regarding training of entrepreneurs throughout the country. Highlight the importance of the accumulation of entrepreneurial human capital in enterprise outcomes and pertained institutions for the transfer of entrepreneurial human capital.

\section{References}

1. Crook TR, Todd SY, Combs JG, Woehr DJ, Ketchen DJ (2011) Does human capital matter? A meta-analysis of the relationship between human capital and firm performance. Journal of Applied Psychology 96: 443.

2. Chimucheka T (2013) The impact of entrepreneurship education on the establishment and survival of small, micro and medium enterprises (SMMEs). Journal of Economics 4: 157-168.

3. McGuirk H, Lenihan H, Hart M (2015) Measuring the impact of innovative human capital on small firms' propensity to innovate. Research Policy 44: 965-976.

4. Sehhat S, Fooman FG (2014) The Impact of Entrepreneurs' Knowledge Dimensions on SME Performance: A Study of SMEs in Iran. Management and Administrative Sciences Review 3: 389-401.

5. Amsden AH (1994) Why isn't the whole world experimenting with the Eas Asian model to develop? Review of the East Asian miracle. World Development 22: $627-633$

6. Bates T (1990) Entrepreneur human capital inputs and small business longevity. The review of Economics and Statistics, pp: 551-559.

7. Becker GS (1964) Human capital: A theoretical and empirical analysis, with Special Reference to Education, University of Chicago press.

8. Shane SA (2003) A general theory of entrepreneurship: The individualopportunity nexus. Edward Elgar Publishing.

9. Deros BM, Mohamed A, Mohamed N (2012) A Study of Alumni Feedback on Outcome based Education in the Faculty of Engineering \& Built Environment Universiti Kebangsaan Malaysia. Procedia-Social and Behavioral Sciences 60: 313-317.

10. Njoroge CW, Gathungu JM (2013) The Effect of Entrepreneurial Education and Training on Development of Small and Medium Size Enterprises in Githunguri District-Kenya. International Journal of Education and Research 1: 1-12.

11. Baptista R, Karaöz M, Mendonça J (2014) The impact of human capital on the early success of necessity versus opportunity-based entrepreneurs. Small Business Economics 42: 831-847.

12. Baptista R, Karaöz M, Mendonça J (2007) Entrepreneurial backgrounds, human capital and start-up success. Jena Economic Research Papers 45: 1-39.

13. Rashid SAS, Lodhi RN, Iqbal A (2013) Intellectual capital and organizational performance: An empirical study in telecom sector of Pakistan. Middle-Eas Journal of Scientific Research 18: 517-523.

14. Schultz TW (1961) Investment in human capital. The American economic review, pp: 1-17

15. Becker GS (2009) Human capital: A theoretical and empirical analysis, with special reference to education: University of Chicago press.

16. Bates $T$ (1985) Entrepreneur human capital endowments and minority business viability. Journal of Human Resources, pp: 540-554.

17. Adams RB, Mehran H (2005) Corporate performance, board structure and its determinants in the banking industry. Paper presented at the EFA 2005 Moscow meetings. 
Citation: Amin S (2018) Does the Entrepreneurial Human Capital is Important for Organizational Performance? Bus Eco J 9: 350. doi: 10.4172/21516219.1000350

Page 5 of 5

18. Zeffane R (2012) Gender and youth entrepreneurial potential: evidence from the United Arab Emirates. International Journal of Business and Management 8: 60 .
19. Haniffa R, Hudaib M (2006) Corporate governance structure and performance of Malaysian listed companies. Journal of Business Finance \& Accounting 33: 1034-1062. 